FOLIA POMERANAE UNIVERSITATIS TECHNOLOGIAE STETINENSIS

Folia Pomer. Univ. Technol. Stetin., Oeconomica 2018, 342(90)1, 29-36

Sylwia GOŁĄB, Beata BĘDZIK

\title{
SATYSFAKCJA Z PRACY A MOTYWACJA DO PODNOSZENIA KWALIFIKACJI ZAWODOWYCH. DONIESIENIA WSTĘPNE Z BADAŃ
}

\author{
JOB SATISFACTION AND MOTIVATION TO IMPROVE PROFESSIONAL \\ QUALIFICATIONS. PRELIMINARY RESULTS OF THE STUDY
}

Katedra Ekonomii i Rachunkowości, Zachodniopomorski Uniwersytet Technologiczny w Szczecinie ul. Żołnierska 47, 71-210 Szczecin, e-mail: sylwia.golab@zut.edu.pl, e-mail: beata.bedzik@zut.edu.pl

\begin{abstract}
Summary. The study aims to clarify the relationship between job satisfaction and motivation to improve professional qualifications. It was conducted among 96 professionally active individuals undertaking further training. The hypotheses have been verified using the Job Satisfaction questionnaire by B. Bajcar, A. Czerw, A. Gąsiorowska (2011). Respondents were also asked about the number of training courses completed in the last six months. The study results indicate that there is a relationship between certain dimensions of job satisfaction and motivation to improve professional qualifications measured by the number of training courses held.
\end{abstract}

Słowa kluczowe: satysfakcja z pracy, podejmowanie szkoleń, kwalifikacje zawodowe, motywacja. Key words: job satisfaction, undertaking training, professional qualifications, motivation.

\section{WSTĘP}

Odczuwanie zadowolenia i satysfakcji z pracy przekłada się nie tylko na efektywność pracownika, ale także na szeroko rozumiane zadowolenie z życia. Praca zajmuje wysokie miejsce w hierarchii wartości wielu osób, wpływa zatem również na jakość życia.

Przegląd literatury dotyczący satysfakcji z pracy wskazuje na wiele niejednoznaczności w definiowaniu tego pojęcia. Można zauważyć, że - pomimo dużego zainteresowania problematyką zadowolenia z pracy - brakuje jednej uniwersalnej definicji oraz badawczych operacjonalizacji. Jedne $z$ pierwszych koncepcji satysfakcji $z$ pracy definiują to pojęcie w kategoriach reakcji emocjonalnych, które są związane z zaspokajaniem potrzeb (Mayo za: Wudarzewski 2013), inne natomiast utożsamiane są z pewną postawą wobec pracy, wynikającą z odczuć, które pojawiają się u jednostki w trakcie procesu pracy (Zalewska 2002; Paszkowska-Rogacz 2009). Rozumienie satysfakcji z pracy jako postawy pojawiło się w latach 60. XX wieku. Wtedy wskazano na dwa aspekty omawianego zagadnienia poznawczy, czyli na ocenę satysfakcji z różnych wymiarów pracy (Czerw i Borkowska 2010), oraz emocjonalny, odnoszący się do odczuć pracownika w pracy i wobec niej (Brief za: Antoniak 2011). Obecne rozumienie zadowolenia z pracy wymaga przeprowadzenia niezależnych badań zarówno jego aspektu emocjonalnego, jak i poznawczego oraz badań związanych z konsekwencjami i czynnikami warunkującymi zadowolenie z pracy (Zalewska 2003). 
W latach 80. i 90. XX wieku nastąpił wzrost zainteresowania satysfakcją z pracy. Zaczęto także w tym kontekście podkreślać znaczenie systemu wartości jednostki, gdyż wartości i motywy mają wpływ na wybory ludzi, określają kontekst sytuacji, a także doświadczenia i działania człowieka (Wudarzewski 2013).

Przegląd literatury nt. satysfakcji z pracy dostarcza wielu definicji i ujęć omawianego zagadnienia. W tabeli 1 zaprezentowano przegląd definicji zaczerpniętych z literatury polskiej i zagranicznej.

Tabela 1. Przegląd definicji satysfakcji z pracy

\begin{tabular}{|l|l|}
\hline \multicolumn{1}{|c|}{ Autor } & \multicolumn{1}{|c|}{ Definicja } \\
\hline $\begin{array}{l}\text { Spector za: Wudarzewski } \\
(2013, \text { s. 329) }\end{array}$ & $\begin{array}{l}\text { "Satysfakcja z pracy to postawa, sposób, w jaki ludzie myślą o swojej pracy } \\
\text { i jej różnych aspektach, co wiąże się z zakresem, w jakim ludzie lubią czy też } \\
\text { nie lubią swojej pracy” }\end{array}$ \\
\hline Brief za: Antoniak (2011, s. 3) & $\begin{array}{l}\text { "Satysfakcja z pracy to wewnętrzny stan, który wyraża się poprzez } \\
\text { emocjonalną i/lub poznawczą ocenę doświadczanej pracy” }\end{array}$ \\
\hline $\begin{array}{l}\text { Drenth i in. za: Białas i Litwin } \\
(2013, \text { s.18) }\end{array}$ & $\begin{array}{l}\text { "Satysfakcja określana jest jako różnica pomiędzy tym, czego człowiek } \\
\text { oczekuje (myśli, że powinien mieć), a tym, czego doświadcza w pracy } \\
\text { (według swojej subiektywnej oceny)" }\end{array}$ \\
\hline Bańka (2000, s. 329) & $\begin{array}{l}\text { "Satysfakcja z pracy jest uczuciową reakcją przyjemności lub przykrości, } \\
\text { doznawaną w związku z wykonywaniem określonych zadań, funkcji oraz ról” }\end{array}$ \\
\hline Zalewska (2003, s. 51) & $\begin{array}{l}\text { "Zadowolenie z pracy jest postawą, która oznacza stan wewnętrzny, ocenę, } \\
\text { w jakim stopniu doświadczana praca jest korzystna bądź niekorzystna dla } \\
\text { osoby, wyrażaną w reakcjach afektywnych i ocenach poznawczych” }\end{array}$ \\
\hline Schulz i Schulz (2002, s. 296) & $\begin{array}{l}\text { "Pozytywne i negatywne uczucia oraz postawy, które odnoszą się do reali- } \\
\text { zowanych przez pracowników obowiązków zawodowych" }\end{array}$ \\
\hline Mrzygłód (2003, s. 2) & $\begin{array}{l}\text { "Satysfakcja z pracy będzie wewnętrznym, subiektywnym odczuciem pracow- } \\
\text { nika i będzie oznaczała pozytywny stosunek do organizacji, współpracow- } \\
\text { ników oraz wykonywanej pracy” }\end{array}$ \\
\hline
\end{tabular}

Źródło: opracowano na podstawie literatury przedmiotu.

Odnosząc się do powyższych definicji, warto podkreślić subiektywny charakter omawianego zagadnienia, nawiązujący do takich czynników, jak: dotychczasowe doświadczenia, indywidualne preferencje, aspiracje, oczekiwania a percepcja określonych sytuacji oraz ich uwarunkowań. Subiektywny charakter satysfakcji nie musi mieć wcale bezpośredniego związku z obiektywną rzeczywistą sytuacją. Innym istotnym czynnikiem warunkującym zadowolenie z pracy, obecnym w powyższych definicjach, są podmiotowe cechy pracownika. Przyczyny odczuwanej satysfakcji należy zatem poszukiwać np. w obszarze osobowości i temperamentu, psychologicznych kompetencji związanych z poznaniem i emocjami oraz w zainteresowaniach zawodowych (Czerw 2017).

Omawiając satysfakcję z pracy, warto podkreślić znaczenie tego zagadnienia w kontekście ogólnie pojętego dobrostanu człowieka. Herzberg i in. (za: Wudarzewski 2013) podkreślają konieczność przeprowadzenia badań satysfakcji z pracy w kontekście trzech obszarów: organizacji, pracownika i społeczeństwa. Badania dotyczące organizacji mogą dotyczyć poziomu wydajności, ze szczególnym uwzględnieniem jej wzrostu, wewnętrznej motywacji, zmniejszenia absencji, konfliktów, co może wpływać na relacje interpersonalne oraz na zmianę miejsca pracy. Z kolei wnioski z badań dotyczące pracowników mogą przełożyć się na większe poczucie szczęścia oraz wzrost samorealizacji, zaś w kontekście społeczeństwa mogą być wykorzystane w celu zwiększenia efektywności zasobów ludzkich czy chociażby wzrostu potencjału ludzkiego (Zalewska 2002; Paszkowska-Rogacz 2009). Warto podkreślić, 
że między tymi czynnikami mogą występować rożnego rodzaju zależności (Leder-Niewola i Waliszewska 2010). Poziom satysfakcji z pracy określać mogą również sądy osoby na temat wykonywanej pracy i stosunek do niej (Zalewska za: Łaguna 2012). Dlatego tak istotne są badania $z$ tego zakresu, podkreślające wielowymiarowość i wieloaspektowość tego zagadnienia.

Zainteresowanie badaczy problematyką satysfakcji z pracy pojawia się także przy okazji takich konstruktów, jak motywacja osiągnięć czy motywacja do rozwoju zawodowego. Satysfakcja pracownika jest konsekwencją jego dokonań; właśnie działanie i jego efekty oraz możliwość samorealizacji często przekładają się na zadowolenie z pracy. W społeczeństwie opartym na wiedzy skutecznym i efektywnym sposobem doskonalenia jest dokształcanie. Różnego rodzaju formy szkoleniowe wspomagają realizację własnych zamierzeń i zadań zawodowych. Nie zawsze, pomimo wielu możliwości dokształcania i korzyści z tego płynących, osoby aktywne, jak również bierne zawodowo korzystają z tego. Wśród uwarunkowań gotowości do podejmowania szkoleń i szeroko pojętego kształcenia można dostrzec czynniki determinujące aktywność osób w tym zakresie. Są to zmienne demograficzne, motywacyjne, jak również zmienne osobowościowe (por. Wyrzykowski 2000). W przypadku szkoleń nabierają znaczenia także czynniki związane ze środowiskiem pracy, czyli te, które związane są bezpośrednio z sytuacją pracy i mogą determinować decyzje odnośnie do dalszego kształcenia (Kawecka i in. 2010).

Podstawowym celem badania było wyjaśnienie relacji między satysfakcją z pracy i jej poszczególnymi wymiarami a motywacją do podejmowania dodatkowej aktywności edukacyjnej mierzonej liczbą odbytych w ciągu ostatnich 6 miesięcy szkoleń. Należy zaznaczyć, że prezentowane wyniki stanowią wycinek prowadzonych przez autorki badań i odnoszą się jedynie do wybranego aspektu poruszanego problemu.

\section{MATERIAŁ I HIPOTEZY BADAWCZE}

W problemie głównym wyodrębniono następujące problemy szczegółowe:

1. Czy istnieje związek między satysfakcją z pracy a motywacją do podnoszenia kwalifikacji zawodowych mierzoną liczbą podejmowanych szkoleń?

Hipoteza 1: Istnieje negatywny związek między satysfakcją z pracy a motywacją do podnoszenia kwalifikacji zawodowych.

2. Czy istnieje związek między zadowoleniem z wyboru zawodu a motywacją do podnoszenia kwalifikacji zawodowych mierzoną liczbą podejmowanych szkoleń?

Hipoteza 2: Istnieje pozytywny związek między satysfakcją $z$ wyboru zawodu a motywacją do podnoszenia kwalifikacji zawodowych.

3. Czy istnieje związek między zadowoleniem z wyboru zawodu a satysfakcją z pracy?

Hipoteza 3: Istnieje pozytywny związek między zadowoleniem z wyboru zawodu a satysfakcją z pracy.

4. Czy istnieje związek między ogólnym zadowoleniem z życia a satysfakcją z pracy?

Hipoteza 4: Istnieje pozytywny związek między ogólnym zadowoleniem z życia a satysfakcją z pracy.

W celu zweryfikowania hipotez zastosowano kwestionariusz satysfakcji z pracy Bajcar i in. (2011). Respondentom zadano także pytanie o liczbę odbytych w ostatnim półroczu szkoleń. 
Kwestionariusz satysfakcja z pracy (Bajcar i in. 2011) składa się z 9 kategorii tworzących obraz satysfakcji z własnej aktywności zawodowej. Do kategorii tych należą: koledzy, bezpośredni przełożeni, rodzaj zadań wykonywanych w pracy, warunki pracy, rozwój zawodowy, wynagrodzenie, czas pracy, stabilność zatrudnienia, firma/ instytucja jako całość. W każdym przypadku badani oceniają, w jakim stopniu są zadowoleni z poszczególnych aspektów związanych z pracą. Ocena ta dokonywana jest $w$ jedenastostopniowej skali dwubiegunowej: od -5 (zupełnie niezadowolony) do +5 (całkowicie zadowolony). Następnie badani ustosunkowali się ( $w$ skali od -5 do +5 ) do polecenia: Oceń teraz, na ile jesteś zadowolony $z$ ogólnych aspektów swojego życia - z tego, że wybrałeś pracę $w$ tym zawodzie; ze swojej pracy jako całości; ze swojego życia jako całości. Sumując wszystkie kategorie, można uzyskać ogólny wskaźnik satysfakcji z pracy. Kwestionariusz ten daje możliwość sprawdzenia także satysfakcji z wyboru swojego zawodu, co stanowi nieco inną perspektywę, niezwiązaną z organizacją $(\alpha=0,85)$ - Czerw (2017).

Analizy statystyczne nieodzowne do weryfikacji zaproponowanych hipotez wykonano w programie IBM SPSS Statistics, w wersji 23. Przy jego użyciu wyliczono podstawowe statystyki opisowe analizowanych zmiennych ilościowych, przetestowano podobieństwo do rozkładu normalnego rozkładów empirycznych, wykonano analizę korelacji $r$ Pearsona. Przyjęto klasyczny próg istotności $p<0,05$.

\section{WYNIKI}

Badanie $^{1}$ przeprowadzono wśród 96 osób aktywnych zawodowo, będących $w$ trakcie dokształcania. Średnia wieku respondentów wynosiła 32 lata, staż pracy w aktualnej firmie wynosił 6 lat, ogółem - 10 lat (tab. 1). W badanej grupie przeważały kobiety, osoby z wykształceniem wyższym magisterskim, pracownicy administracyjni, niebędący kierownikami (tab. 2). W tabeli 3 zaprezentowano statystyki opisowe badanych zmiennych.

Tabela 1. Charakterystyka badanej próby $(N=96)$

\begin{tabular}{|l|c|c|c|c|}
\cline { 2 - 5 } \multicolumn{1}{c|}{} & Minimum & Maksimum & Średnia & $S D$ \\
\hline Wiek & 19 & 64 & 32,32 & 9,59 \\
\hline Staż ogółem & 1 & 40 & 9,50 & 7,69 \\
\hline Staż w aktualnej organizacji & 0 & 24 & 6,06 & 6,31 \\
\hline
\end{tabular}

Tabela 2. Charakterystyka badanej próby $(N=96)$

\begin{tabular}{|c|c|c|c|}
\hline & & \\
\hline & & Liczba & Procent \\
\hline \multirow{2}{*}{ Płeć } & kobiety & 77 & 80,2 \\
\hline & mężczyźni & 19 & 19,8 \\
\hline \multirow{2}{*}{ Stanowisko } & kierownicze & 17 & 17,7 \\
\hline & niekierownicze & 79 & 82,3 \\
\hline \multirow{3}{*}{ Wykształcenie } & średnie & 21 & 21,9 \\
\hline & licencjat/ inżynier & 31 & 32,3 \\
\hline & wyższe magisterskie & 44 & 45,8 \\
\hline \multirow{5}{*}{ Rodzaj stanowiska } & pracownik administracyjny & 29 & 30,2 \\
\hline & pracownik obsługi klienta & 17 & 17,7 \\
\hline & pracownik produkcyjny & 1 & 1,0 \\
\hline & specjalista & 24 & 25,0 \\
\hline & inny & 25 & 26,0 \\
\hline
\end{tabular}

\footnotetext{
${ }^{1}$ Badanie przeprowadzono w okresie $09.2017-01.2018$.
} 
Tabela 3. Statystyki opisowe dla badanych zmiennych $(N=96)$

\begin{tabular}{|l|c|c|c|c|}
\cline { 2 - 5 } \multicolumn{1}{c|}{} & Minimum & Maksimum & Średnia & $S D$ \\
\hline Koledzy & $-4,00$ & 5,00 & 3,4271 & 1,90702 \\
\hline Bezpośredni przełożeni & $-5,00$ & 5,00 & 2,5417 & 2,94124 \\
\hline $\begin{array}{l}\text { Rodzaj zadań wykonywanych } \\
\text { w pracy }\end{array}$ & $-5,00$ & 5,00 & 2,8021 & 2,34238 \\
\hline Warunki pracy & $-5,00$ & 5,00 & 3,0104 & 2,15453 \\
\hline Rozwój zawodowy & $-5,00$ & 5,00 & 2,0000 & 3,02620 \\
\hline Wynagrodzenie & $-5,00$ & 5,00 & 1,9479 & 2,76584 \\
\hline Czas pracy & $-5,00$ & 5,00 & 2,9375 & 2,26559 \\
\hline Stabilność zatrudnienia & $-5,00$ & 5,00 & 2,6563 & 2,97650 \\
\hline Firma/ instytucja jako całość & $-5,00$ & 5,00 & 2,5729 & 2,46553 \\
\hline Zadowolenie z pracy & $-5,00$ & 5,00 & 2,3542 & 2,95218 \\
\hline Zadowolenie z życia & $-2,00$ & 5,00 & 3,7292 & 1,45442 \\
\hline Liczba szkoleń & 1,00 & 5,00 & 1,4896 & 0,96240 \\
\hline
\end{tabular}

W celu weryfikacji hipotezy o związku poziomu satysfakcji z pracy z motywacją do podnoszenia kwalifikacji zawodowych wykonano analizę korelacji Pearsona. Analiza korelacji nie wykazała zależności między satysfakcją z pracy, a liczbą podejmowanych szkoleń $(r=0,195, p>0,05)$, dlatego hipoteza 1 nie została potwierdzona. Jeśli jednak dokonamy szczegółowej analizy poszczególnych wymiarów satysfakcji z pracy, zauważymy pozytywny związek między rozwojem zawodowym a motywacją do podejmowania dodatkowej działalności edukacyjnej $(r=0,253, p>0,05)$. Potwierdzono także hipotezę o związku między zadowoleniem $\mathrm{z}$ wyboru zawodu a motywacją do podnoszenia kwalifikacji zawodowych $(r=0,590, p>0,05)$. Im wyższy był poziom zadowolenia $z$ wyboru zawodu, tym wyższa była aktywność w podejmowaniu szkoleń.

Następnie sprawdzono (analiza korelacji Pearsona) hipotezę dotyczącą związku między zadowoleniem z wyboru zawodu a satysfakcją z pracy i jej poszczególnymi wymiarami. Analizy pokazały, że istnieje potwierdzona statystycznie zależność między badanymi zmiennymi. Im większe jest zadowolenie z wyboru zawodu, tym wyższa satysfakcja z pracy. Dokonując szczegółowej analizy, można zauważyć, że istnieją związki między zadowoleniem z wyboru zawodu a poszczególnymi wymiarami satysfakcji z pracy. Nie obserwuje się zależności jedynie w odniesieniu do kolegów z pracy oraz stabilności zatrudnienia (tab. 4).

Tabela 4. Zależności między satysfakcją z pracy a zadowoleniem z wyboru zawodu $(N=96)$

\begin{tabular}{|l|c|}
\hline \multicolumn{1}{|c|}{ Wyszczególnienie } & \multicolumn{1}{|c|}{ Zadowolenie $z$ wyboru zawodu } \\
\hline Koledzy & 0,137 \\
\hline Bezpośredni przełożeni & $0,414^{* *}$ \\
\hline Rodzaj zadań wykonywanych w pracy & $0,671^{* *}$ \\
\hline Warunki pracy & $0,148^{\star *}$ \\
\hline Rozwój zawodowy & $0,741^{* *}$ \\
\hline Wynagrodzenie & $0,346^{* *}$ \\
\hline Czas pracy & $0,254^{*}$ \\
\hline Stabilność zatrudnienia & 0,190 \\
\hline Firma/ instytucja jako całość & $0,433^{\star *}$ \\
\hline Ogólna satysfakcja z pracy & $0,588^{* *}$ \\
\hline
\end{tabular}

* Korelacja istotna na poziomie 0,05 (dwustronnie).

** Korelacja istotna na poziomie 0,01 (dwustronnie). 
Następnie dokonano weryfikacji hipotezy o związku poziomu satysfakcji z pracy z zadowoleniem z życia jako całości. Analiza korelacji wykazała, że istnieje zależność między badanymi zmiennymi (tab. 5). Obserwuje się także związki między poszczególnymi wymiarami satysfakcji z pracy a ogólnym zadowoleniem z życia. Przeprowadzone analizy nie wykazały zależności jedynie między rodzajem wykonywanych zadań a stabilnością zatrudnienia.

Tabela 5. Zależności między satysfakcją z pracy, a zadowoleniem z życia jako całości $(N=96)$

\begin{tabular}{|l|l|}
\hline \multicolumn{1}{|c|}{ Wyszczególnienie } & \multicolumn{1}{c|}{ Zadowolenie z życia jako całości } \\
\hline Koledzy & $0,236^{\star}$ \\
\hline Bezpośredni przełożeni & $0,298^{\star *}$ \\
\hline Rodzaj zadań wykonywanych w pracy & 0,197 \\
\hline Warunki pracy & $0,313^{\star *}$ \\
\hline Rozwój zawodowy & $0,206^{\star}$ \\
\hline Wynagrodzenie & $0,282^{\star \star}$ \\
\hline Czas pracy & $0,295^{\star *}$ \\
\hline Stabilność zatrudnienia & 0,173 \\
\hline Firma/ instytucja jako całośćc & $0,290^{\star *}$ \\
\hline Ogólna satysfakcja z pracy & $0,362^{\star \star}$ \\
\hline
\end{tabular}

${ }^{*}$ Korelacja istotna na poziomie 0,05 (dwustronnie).

${ }^{* *}$ Korelacja istotna na poziomie 0,01 (dwustronnie).

\section{PODSUMOWANIE}

Wyniki przeprowadzonych badań wskazują, że odczuwanie satysfakcji z pracy może być związane z motywacją do podejmowania dodatkowej aktywności edukacyjnej. Uzyskane wyniki nie są jednak jednoznaczne. Co prawda, nie zaobserwowano zależności między ogólnym poziomem satysfakcji z pracy a motywacją do podnoszenia kwalifikacji zawodowych, ale stwierdzono pozytywny związek między rozwojem zawodowym a liczbą podejmowanych szkoleń. Jest to zrozumiałe, gdyż szkolenia są wpisane w każdą organizację, coraz częściej mówi się także o znaczeniu organizacji opartej na wiedzy. Warto podkreślić, że interesujące mogą okazać się badania pokazujące zależności między dobrostanem w miejscu pracy a różnymi typami podejmowanej aktywności edukacyjnej, gdyż nie zawsze dokształcanie pracowników ma związek z zajmowanym stanowiskiem pracy i konkretną organizacją.

Zaprezentowane wyniki badań wykazały także, że istnieje zależność między zadowoleniem z wyboru zawodu a satysfakcją z pracy. Może to być cenna wskazówka dla instytucji zajmujących się doradztwem zawodowym, gdyż satysfakcja z pracy może być nie tylko skutkiem, ale także czynnikiem motywującym do podejmowania szkoleń. Jest to szczególnie ważne, gdyż wraz z rozwojem społeczno-gospodarczym obserwuje się dezaktualizację kwalifikacji i kompetencji pracowników, zaś różne formy dokształcania przyczyniają się do zapewniania odpowiedniego poziomu wiedzy i umiejętności. 


\section{PIŚMIENNICTWO}

Antoniak E. 2011. Time perspective and job satisfaction in professionals oriented towards people and towards objects. Hum. Res. Manag. Ergonom. 5(1), 1- 2.

Bajcar B., Borkowska A., Czerw A., Gąsiorowska A. 2011. Satysfakcja z pracy w zawodach z misją społeczną: psychologiczne uwarunkowania. Gdańsk, Gdań. Wydaw. Psych.

Bańka A. 2000. Psychologia organizacji, w: Psychologia. Podręcznik akademicki, t. 3. Red. J. Strelau, Gdańsk, GWP, 321-349.

Białas S., Litwin J. 2013. Satysfakcja z pracy i przejawy zachowań kontr produktywnych wśród pracowników spółki przemysłu stoczniowego. Studium przypadku. Zarz. Finan. 4(1), 17-29.

Cable D.M., Edwards J.R. 2004. Complementary and supplementary fit: A theoretical and empirical integration. J. App. Psych. 89(5), 822-834. DOI: 10.1037/0021-9010.89.5.822.

Czerw A. 2017. Psychologiczny model dobrostanu w pracy. Wartość i sens pracy. Warszawa, Wydaw. Nauk. PWN.

Czerw A., Borkowska A. 2010. Praca zawodowa jako obszar realizowania misji społecznej. Psych. Społ. 5 (4), 303-315.

Czerw A., Czarnota-Bojarska J. 2016. Dopasowanie człowiek - środowisko i postawa wobec pracy jako motywatory zachowań organizacyjnych. Psych. Społ. 1 (36), 8-19.

Kawecka K., Łaguna M., Tabor K. 2010. Gotowości do podejmowania szkoleń i dalszego kształcenia. Propozycja ujęcia teoretycznego i skal pomiaru. Org. Kier. 2(140), 43-55.

Leder-Niewola B., Waliszewska G. 2010. Związek między skuteczną komunikacją w bibliotece naukowej a satysfakcją pracowników w świetle badań ankietowych. Marketing wewnętrzny Biblioteki Uniwersytetu Łódzkiego, w: Marketing wewnętrzny i zarządzanie zasobami ludzkimi w bibliotece. Red. H. Brzezińska-Stec, J. Kudrawiec. Białystok, Wydaw. Uniw. w Białymstoku, 193-217.

Łaguna M. 2012. Satysfakcja z życia i satysfakcja z pracy a motywacja do podejmowania szkoleń. Doniesienie z badań. Psychol. Jakości Życia 12(2), 163-172.

Mrzygłód J. 2003. Badanie postaw i satysfakcji pracowników. Personel 22, 2- 3.

Paszkowska-Rogacz A. 2009. Doradztwo zawodowe. Wybrane metody badań. Warszawa, Difin.

Schulz D.P., Schulz S.E. 2002. Psychologia a wyzwania dzisiejszej pracy. Warszawa, PWN.

Terelak J.F. Jankowska P. 2009. Dopasowanie jednostka - organizacja a zadowolenie z pracy. Stud. Mater. Miscellanea Oeconomicae 13(1), 229-254, http://docplayer.pl/31301904-Dopasowaniejednostka-organizacja-a-zadowolenie-z-pracy.html, dostęp: 27.05.2018.

Wudarzewski G. 2013. Satysfakcja z pracy - konceptualizacja pojęcia w świetle badań literaturowych. Zesz. Nauk. Wyż. Szk. Bank. Wroc. 5(37), 330-331.

Zalewska A. 2002. Skala afektu w pracy - wstępne wyniki prac nad adaptacją techniki. Stud. Psychol. 40, 173-192.

Zalewska A. 2003. Skala satysfakcji z pracy - pomiar poznawczego aspektu ogólnego zadowolenia z pracy. Acta Univ. Lodz., Folia Psychologica 7, 49-52.

Streszczenie. Celem badań było wyjaśnienie relacji między satysfakcją z pracy a motywacją do podnoszenia kwalifikacji zawodowych. Badanie przeprowadzono wśród 96 osób aktywnych zawodowo, w trakcie dokształcania. Do weryfikacji hipotez wykorzystano kwestionariusz satysfakcji z pracy Bajcar i in. (2011). Respondentom zadano także pytanie o liczbę szkoleń odbytych w ostatnim półroczu. Uzyskane wyniki badań wskazują, że istnieją zależności między poszczególnymi wymiarami satysfakcji z pracy a motywacją do podnoszenia kwalifikacji zawodowych, mierzoną liczbą podejmowanych szkoleń. 
